\title{
PHYSIOLOGY AND YIELD OF PIEL DE SAPO MELON (Cucumis melo L.) UNDER WATER DEFICIT IN SEMI-ARID REGION, BRAZIL
}

\author{
FISIOLOGIA E RENDIMENTO DO MELOEIRO PELE-DE-SAPO (Cucumis melo L.) \\ CULTIVADO SOB DIFERENTES REGIMES HÍDRICOS EM REGIÃO SEMIÁRIDA,
} BRASIL

\begin{abstract}
Alberto Soares de MELO ${ }^{1}$; Vandeir Gouveia DIAS ${ }^{1}$; Wellison Filgueiras DUTRA ${ }^{2}$; Alexson Filgueiras DUTRA ${ }^{3}$; Francisco Vanies da Silva SÁ ${ }^{4}$; Marcos Eric Barbosa BRITO ${ }^{5}$; Pedro Roberto Almeida VIÉGAS ${ }^{6}$

1. Universidade Estadual da Paraíba, Department of Biological Science, Campina Grande, Paraíba, Brazil. alberto@uepb.edu.br; 2. Universidade Federal da Paraíba, Center of Agricultural Sciences, Areia, Paraíba, Brazil; 3 Universidade Estadual Paulista Júlio de Mesquita, Departament of Agronomy, Jaboticabal, São Paulo, Brazil; 4. Universidade Federal Rural do Semi-Árido, Center of Agrarian Sciences, Mossoró, RN, Brazil. vanies_agronomia@hotmail.com; 5. Universidade Federal de Sergipe, Campus do Sertão, Nossa Senhora da Glória, SE, Brazil; 6. Universidade Federal de Sergipe, São Cristóvão, Sergipe, Brazil.
\end{abstract}

\begin{abstract}
Melon (Cucumis melo L.) is a crop of great socioeconomic importance in regions with semiarid climate, as found in Northeast Brazil. In this region water deficit is a usual condition as well as the main reduction factor of plant productivity. Due to this phenomenon, irrigation techniques are used to make available the amount of water needed for plant production. Therefore, this study evaluated the physiology and fruit production changes of 'Juazeiro' Piel de sapo melon plants under different water replacement rates. 'Juazeiro' melon was grown under four reference evapotranspiration replacement rates $(40,60,80$ and $100 \%$ of ETo) distributed randomly in blocks with 5 replicates. The plants were cultivated in the field, in an experimental area located in the Brazilian Northeast region, under hot and dry semiarid climatic conditions, and during the growing cycle the 'Juazeiro' hybrid melon plants were evaluated for leaf area, biomass accumulation, gas exchange, photochemical efficiency of photosystem PSII and production of fruits per plant. Application of water replacement rates of $100 \%$ ETo leads to highest growth, net photosynthesis, and fruit yield of 'Juazeiro' melon. Water replacement at $80 \%$ ETo can be used for 'Juazeiro" melon under semiarid climatic conditions, but with small losses in fruit yield. Water replacement below 80\% ETo leads to drastic reductions in growth, gas exchanges, quantum efficiency of photosystem II and fruit yield, which impairs melon production in semi-arid climate environments.
\end{abstract}

KEYWORDS: Fruits yield. Gas exchange. Photochemical efficiency.

\section{INTRODUCTION}

Melon (Cucumis melo L.) is an important socioeconomic fruit cultivated in the world. Melon fruit production was 29.6 million tons and this production is distributed among China, Turkey, Iran, Egypt, India, United States, and Brazil. These countries account for $70 \%$ of the world production (FAO, 2017). In Brazil, cultivated area exceeded 22.000 ha with more than 521.6 thousand tons in 2015. $94.7 \%$ of this production was obtained in the semi-arid region of Northeast, mainly in the states of Ceará and Rio Grande do Norte, the largest producers in the country (IBGE, 2014).

However, especially due to irregular rainfall, melon fruit production has been dropping in the last few years in this region. According to Pereira Filho et al. (2015), melon plants growth, development, and fruit production are greatly affected by climate conditions, mainly by water stress.

Water stress is one of the most complex physiological phenomena because it is a multidimensional component which can considerably limit agricultural crops growth and development (DOGAN et al., 2008; LISAR et al., 2012; SILVA et al., 2015), generally in arid and semi-arid regions, such as in Northeast Brazil. Moreover, plant adaptability to water deficit conditions is related to a range of events occurring at several levels (LISAR et al., 2012), observed as a physiological, biochemical, and molecular adaptations, among others.

At plant physiological level, soil water deficit has a significant effect on gas exchange, because it is a result of the limitation of stomatal conductance, and it is considered the primary cause of photosynthetic inhibition due to $\mathrm{CO}_{2}$ influx limitation, as well as water efflux from transpiration 
Physiology and yield...

(ENDRES et al., 2010; MELO et al., 2010; SINGH; REDDY, 2011; NINOU et al., 2013; FERRAZ et al., 2014; SILVA et al., 2015). Therefore, evaluating gas exchange may help in understanding melon plant responses to soil water deficit, in addition to quantify the acclimatization capacity of this specie to this kind of adverse condition.

Yet, the decrease of photosynthetic efficiency in plants under water stress is not only related to stomatal causes, but also to the metabolic inefficiency of the photosynthetic mechanism, associated with the quantitative and qualitative changes in the activity of enzymes and metabolites, low carboxylation efficiency, and inhibition of chloroplast activity (LISAR et al., 2012). Under stress conditions, plants undergo changes in the quantum efficiency of the photosystem II, which can be verified by determining the fluorescence of chlorophyll $a$.

Therefore, there is a need for detailed understanding of the physiological mechanisms of water stress tolerance to develop adequate water remediation techniques for melon plants, with the further goal of optimizing fruit production and water use by this crop. It is worth pointing out that using the irrigation technique is necessary to meet melon water demand in semi-arid regions (DOGAN et al., 2008; SUASSUNA et al., 2011), because this species is generally cultivated in drought periods.

In semi-arid region, low water volume irrigation (less than evapotranspiration) may be a tool to save water. However, it is necessary to carry out studies to measure physiological, fruit production responses under different water conditions, and identify which techniques allow water savings with the concomitant increase or maintenance of melon productivity. Thus, this study aimed to evaluate 'Juazeiro' Piel de sapo melon physiological and fruit production variations under different water replacement rates.

\section{MATERIAL AND METHODS}

\section{Plant material and growing conditions}

Hybrid 'Juazeiro' Piel de sapo melon was grown in the experimental area at the Paraíba State University, municipality of Catolé do Rocha,

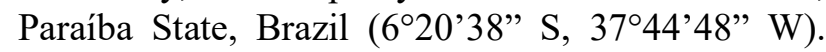
The research was carried out from September to December of 2012, throughout the drought period in the region.

The soil was classified as Neossolo Flúvico Eutrófico (Entisol) with sandy loam texture (EMBRAPA, 2013), and the following physicochemical characteristics: sand $=773.7 \mathrm{~g} \mathrm{~kg}^{-1}$; silt $=$
MELO, A. S. et al.

$168.3 \mathrm{~g} \mathrm{~kg}^{-1}$; clay $=58 \mathrm{~g} \mathrm{~kg}^{-1}$; bulk density $=1.53 \mathrm{~g}$ $\mathrm{cm}^{-3}$; actual density $=2.65 \mathrm{~g} \mathrm{~cm}^{-3}$; total porosity $=$ $42.26 \% ; \mathrm{pH}\left(\mathrm{H}_{2} \mathrm{O}\right)=7.54 ; \mathrm{P}($ Mehlich $)=186.87 \mathrm{mg}$ $\mathrm{dm}^{-3} ; \mathrm{K}^{+}=309.08 \mathrm{mg} \mathrm{dm}{ }^{-3} ; \mathrm{Na}^{+}=0.413 \mathrm{cmol}_{\mathrm{c}} \mathrm{dm}^{-3}$; $\mathrm{Ca}^{+2}=4.8 \mathrm{cmol}_{\mathrm{c}} \mathrm{dm}^{-3} ; \mathrm{Mg}^{+2}=1.55 \mathrm{cmol}_{\mathrm{c}} \mathrm{dm}^{-3} ;$ organic matter $=12.62 \mathrm{~g} \mathrm{~kg}^{-1} ; \mathrm{H}^{+}+\mathrm{Al}^{+3}=0.413$ $\mathrm{cmol}_{\mathrm{c}} \mathrm{dm}^{-3} ; \mathrm{Al}^{+3}=0.0 \mathrm{cmol}_{\mathrm{c}} \mathrm{dm}^{-3}$; cation exchange capacity $=7.96 \mathrm{cmol}_{\mathrm{c}} \mathrm{dm}^{-3}$; sum of bases $=5.64$ $\mathrm{cmol}_{\mathrm{c}} \mathrm{dm}^{-3}$; and base saturation $=94.82 \%$.

The soil was plowed at $20 \mathrm{~cm}$ depth by a disc plough and leveled by a levelling harrow. Furrows with $15 \mathrm{~cm}$ depth were opened for cattle manure application $\left(2.0 \mathrm{~L} \mathrm{~m}^{-1}\right)$ along with $40 \mathrm{~kg} \mathrm{ha}^{-1}$ of $\mathrm{P}_{2} \mathrm{O}_{5}$; all furrows were closed with the ridges. According to soil analysis and melon plants nutritional requirement (CAVALCANTI, 2008), 80 and $40 \mathrm{~kg} \mathrm{ha}^{-1}$ of $\mathrm{N}$ and $\mathrm{K}_{2} \mathrm{O}$ were applied as topdressing fertilization respectively by fertigation every seven days. NPK sources were: urea $(45 \%$ of $\mathrm{N})$, single superphosphate $\left(22 \%\right.$ of $\left.\mathrm{P}_{2} \mathrm{O}_{5}\right)$, and potassium chloride $\left(60 \%\right.$ of $\left.\mathrm{K}_{2} \mathrm{O}\right)$.

Sowing was done in $2 \times 0.3 \mathrm{~m}$ planting rows with 3 seeds per hole. Seedlings were thinned 15 days after sowing (DAS) to leave just one seedling per hole. During seedling initial growth, weeds were controlled only above ridges. Sudan grass (Sorghum sudanense L.) dry straw was placed above the ridges to prevent weed infestation and soil water evaporation.

At 15 DAS, treatments corresponding to four reference evapotranspiration replacement rates (ETo: 40, 60, 80, and 100\%) were applied. These values were calculated by Penman-Monteith (ALLEN et al., 1998). Soil water, application intensity, and irrigation time were determined according to Mantovani, Bernado and Paloretti (2006). Irrigation was performed according to the respective ETo replacement rates through drip tape with emitters with flow rate of $1.5 \mathrm{~L} \mathrm{~h}^{-1}$ and set at every $0.2 \mathrm{~m}$. Climatological data used to calculate ETo were obtained daily at the agrometeorological station located near the experimental area. Air temperature $\left({ }^{\circ} \mathrm{C}\right.$ day $\left.^{-1}\right)$, relative humidity $(\%)$, and solar radiation $\left(\mathrm{MJ}\right.$ day $\left.^{-1}\right)$ were obtained during experimental period (Figure 1).

\section{Growth analysis}

Leaf area (LA) and leaves (LDM), branches (BDM), and total dry matter (TDM) were quantified at seven-day intervals, beginning at 20 DAS and finishing at 55 DAS. LA $\left(\mathrm{cm}^{2}\right)$ was quantified by adopting a model according to Nascimento et al. (2002), which uses the length measurements of hole plant leaves. Afterward, melon plants were collected and divided into leaves and stem. Each plant part 
was put into paper bags to be dried in forced air circulation oven regulated to $70{ }^{\circ} \mathrm{C}$ until reaching constant weight. LDM and BDM values were attained on semi-analytic scale (Marconi) $(\mathrm{e}=0.01$ g), while TDM was obtained through the sum of LDM plus BDM.

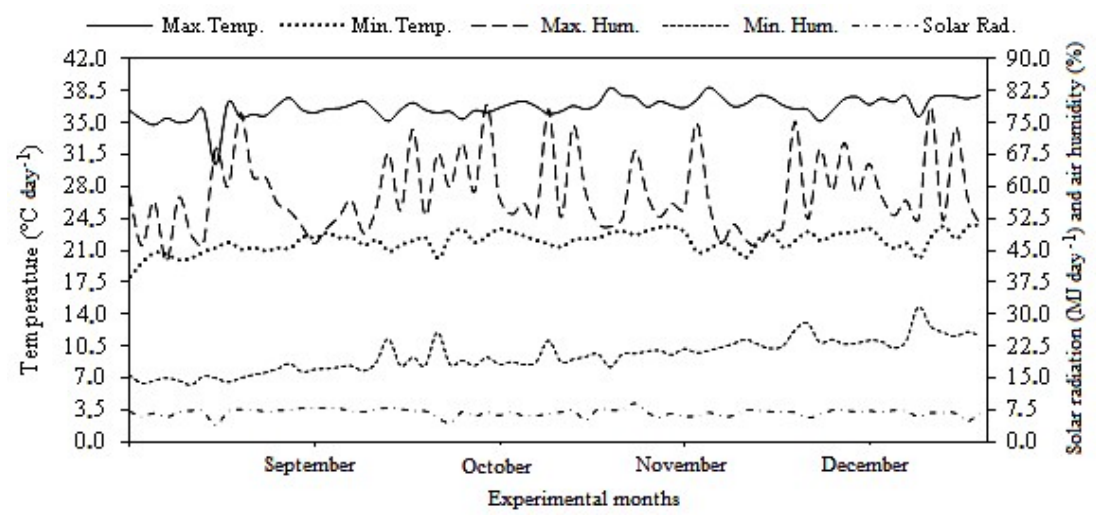

Figure 1. Air temperature variation (Max. and Min. Temp.), relative humidity (Max. and Min. Hum.), and solar radiation (Solar Rad.) obtained during the experimental period.

\section{Gas exchanges and quantum efficiency of photosystem II}

Maximum quantum efficiency of PSII was evaluated in the middle third of the main branch at 35 DAS, between 7 and 9 a.m., by an infrared gas analyzer (ACD, model LCPro SD, Hoddesdon, UK), with airflow of $300 \mu \mathrm{mol} \mathrm{min} \mathrm{m}^{-1}$ and an attached light

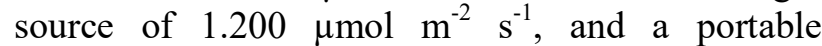
fluorometer (Hansatech). All following parameters were obtained according to Melo et al. (2010), Suassuna et al. (2011), and Silva et al. (2015): stomatal conductance (gs - mmol $\mathrm{H}_{2} \mathrm{O} \mathrm{m} \mathrm{m}^{-2} \mathrm{~s}^{-1}$ ); internal carbon concentration $\left(\mathrm{Ci}-\mu \mathrm{mol} \mathrm{CO} \mathrm{CO}^{-2} \mathrm{~s}^{-}\right.$ $\left.{ }^{1}\right)$; transpiration ( $\left.\mathrm{E}-\mathrm{mmol} \mathrm{H}_{2} \mathrm{O} \mathrm{m} \mathrm{m}^{-2} \mathrm{~s}^{-1}\right)$; net

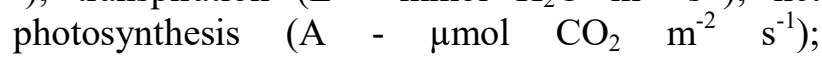
instantaneous water use efficiency $(\mathrm{A} / \mathrm{E}$ - iWUE $\mu \mathrm{mol} \mathrm{CO}_{2} \mathrm{mmol}^{-1} \mathrm{H}_{2} \mathrm{O}$ ); and quantum efficiency of photosystem II ( $\mathrm{Fv} / \mathrm{Fm})$, calculated by the relation between variable (Fv) and maximum (Fm) fluorescence.

\section{Fruit yield}

Two fruits per plant were standardized to obtain commercial fruits, and to calculate the production of 'Juazeiro' melon; these fruits were harvested at the end of the crop cycle (96 days). Fruit weight was obtained with a semi-analytical scale (Marconi) $(\mathrm{e}=0.01)$.

\section{Experimental design and statistical analysis}

Experimental design was a randomized block with 5 replicates. Experimental plot was composed of a row of 16 plants, but 8 plants from the center of the row were used for analyses and fruit production. Data were submitted to analysis of variance by the $F$ test $(\alpha \leq 0.05)$ and regression models were fitted according to the coefficient of determination $(\alpha \leq 0.05)$ by SAEG 9.1 and SigmaPlot 12.5 programs.

\section{RESULTS AND DISCUSSION}

Water replacement rates had a significant effect on 'Juazeiro' melon leaf area and dry matter accumulation. Leaf area, as a function of days after sowing, was described by a sigmoidal model. In relation to plant age, the largest increases in leaf area were observed between 27 and 48 DAS at all irrigation rates, but it was more significant when 100\% ETo was applied (Figure 2A). At 48 DAS there was a decline in 'Juazeiro' melon leaf area related to all irrigation rates studied. A similar tendency was verified by Medeiros et al. (2012) and Terceiro Neto et al. (2014) when these authors evaluated Piel de sapo melon growth in relation to different salinity levels and plants development stages. Leaf area decline is related to the beginning of leaf senescence and shading caused by the upper branches (MEDEIROS et al., 2012). It can be observed that the larger leaf area indicates a better production of photoassimilates for increasing the photosynthetic capacity of melon plants, which has direct relation to optimal fruit organoleptic characteristics. Therefore, this justifies the strong correlation $\left(\mathrm{r}=0.97^{* *}\right)$ between leaf area and fruit yield (Table 1).

In relation to water replacement rates, the highest leaf area value was achieved at 48 DAS with $100 \%$ ETo application. However, on this same date, there was no significant difference between 100, 80, 
Physiology and yield...

and $60 \%$ ETo rates (Figure 2A). On the other hand, lower values of leaf area were noted with $40 \%$ ETo rates, which demonstrates the sensitivity of melon plants to the lower water availability in the soil. In accordance with Pereira Filho et al. (2015), the increase of stomatal resistance and the decrease of $\mathrm{CO}_{2}$ influx determine the lowest water loss due to transpiration, besides being able to affect the
MELO, A. S. et al.

photosynthesis. This is related to the lower stomatal conductance (gs) due to soil water deficit, which caused a reduction in the net photosynthesis (A) and, consequently, decrease of leaf expansion, fact observed in Juazeiro melon, which validates the positive and significant correlation observed for these variables (Table 1).
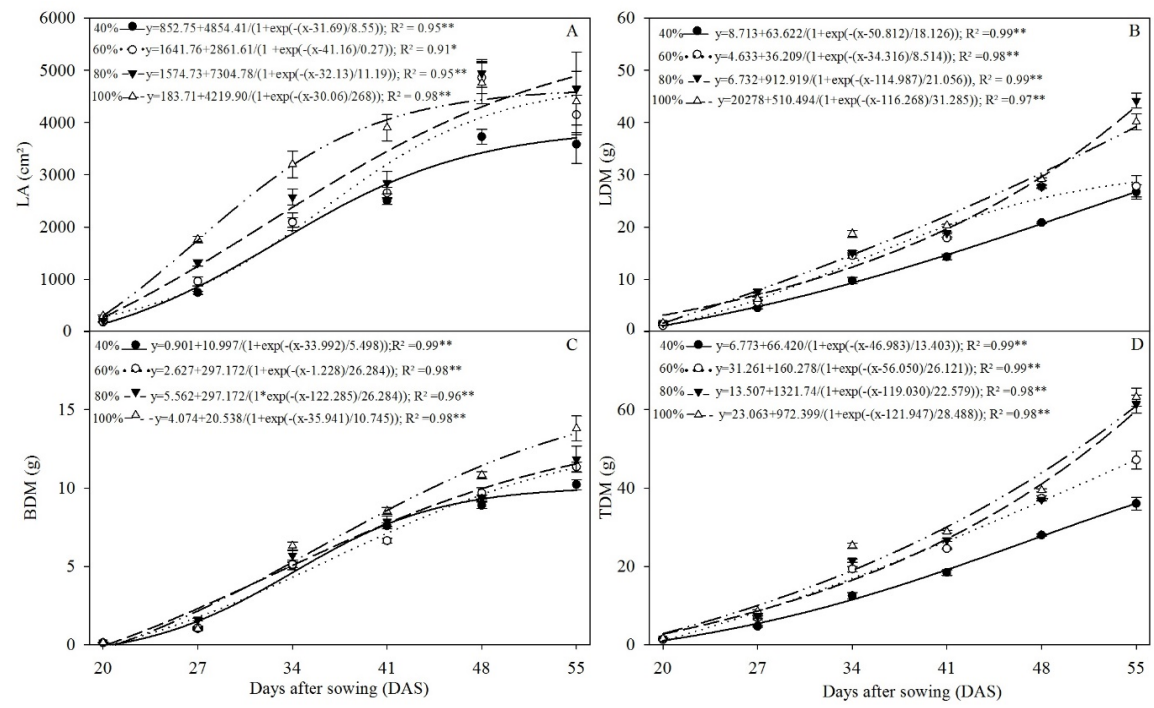

Figure 2. 'Juazeiro' melon leaf area (LA) (a), leaf dry matter (LDM) (b), branch dry matter (BDM) (c) and total dry matter (TDM) (d) at days after sowing (DAS) and ETo replacement rates.

Table 1. Pearson's linear correlation among variables: leaf area (LA), leaf dry matter (LDM), branch dry matter (BDM), total dry matter (TDM), stomatal conductance (gs), internal carbon concentration (Ci), transpiration (E), net photosynthesis (A), intrinsic water use efficiency (iWUE), quantum efficiency of PSII (Fv/Fm), and fruit production (Yield).

\begin{tabular}{llllllllllll}
\hline & LA & LDM & BDM & TDM & Gs & Ci & E & A & iWUE & Fv/Fm & Yield \\
\hline LA & 1 & 0.86 & 0.89 & 0.89 & 0.96 & 0.92 & 0.77 & 0.99 & 0.57 & 0.87 & 0.97 \\
LDM & $* *$ & 1 & 0.94 & 0.97 & 0.73 & 0.93 & 0.34 & 0.89 & 0.91 & 0.99 & 0.96 \\
BDM & $* *$ & $* *$ & 1 & 0.99 & 0.73 & 0.83 & 0.46 & 0.93 & 0.82 & 0.98 & 0.95 \\
TDM & $* *$ & $* *$ & $* *$ & 1 & 0.93 & 0.87 & 0.42 & 0.93 & 0.86 & 0.99 & 0.97 \\
gS & $* *$ & $* *$ & $* *$ & & 1 & 0.88 & 0.87 & 0.92 & 0.37 & 0.71 & 0.88 \\
Ci & $* *$ & $* *$ & $* *$ & $* *$ & $* *$ & 1 & 0.53 & 0.91 & 0.73 & 0.89 & 0.95 \\
E & $* *$ & ns & $*$ & $*$ & $* *$ & $* *$ & 1 & 0.71 & -0.08 & 0.37 & 0.59 \\
A & $* *$ & $* *$ & $* *$ & $* *$ & $* *$ & $* *$ & $* *$ & 1 & 0.63 & 0.91 & 0.98 \\
iWUE & $* *$ & $* *$ & $* *$ & $* *$ & ns & $* *$ & ns & $* *$ & 1 & 0.89 & 0.76 \\
Fv/Fm & $* *$ & $* *$ & $* *$ & $* *$ & $* *$ & $* *$ & $*$ & $* *$ & $* *$ & 1 & 0.96 \\
Yield & $* *$ & $* *$ & $* *$ & $* *$ & $* *$ & $* *$ & $* *$ & $* *$ & $* *$ & $* *$ & 1 \\
\hline
\end{tabular}

ns $* *$ and $*$ : not significant and significant at $1 \%$ and $5 \%$ probability.

Unlike leaf area, the greatest accumulation of 'Juazeiro' melon dry matter occurred at 55 DAS with the application of the higher rates of ETo (Figure 2A). In the leaf and total dry matter, there were no statistical changes between 80 and 100\% ETo rates. In contrast, replacement of $100 \%$ promoted a significant increase in branch dry matter from 41 DAS, when compared to the others replacement rates. It should also be highlighted that
'Juazeiro' melon dry matter accumulation was positively correlated with leaf area (Table1). The lowest accumulations of leaf, branch, and total dry matter in melon plants with smaller leaf area were observed at 40\% ETo (Figure 2B, 2C and 2D). The reduction in leaf expansion associated with the increase of stomatal resistance leads to changes in plant's ability to intercept and utilize photosynthetically active radiation (PINHEIRO 
Physiology and yield...

NETO et al., 2007), which decreases photoassimilates and, therefore, decreases leaf, branch, and total dry matter in melon plants. This behavior was confirmed by the strong correlation observed among 'Juazeiro' melon leaf area, leaf dry matter, branch dry matter and total dry matter, as well as net photosynthesis (A) (Table 1).

Reducing water availability significantly influenced Piel de sapo melon gas exchange (Figure 3 ). Stomatal conductance (gs) was reduced due to soil water availability (Figure 3A). The same propensity was also found for the internal carbon concentration $(\mathrm{Ci})$ (Figure $3 \mathrm{~b}$ ), transpiration $(\mathrm{E})$, and net photosynthesis (A) (Figure 3D). Variation of replacement rate from 40 to $100 \%$ of the reference evapotranspiration (ETo) led to increments on the order of $136.4,26.56,52.95$, and $74.4 \%$ in stomatal conductance, internal carbon concentration, transpiration and net photosynthesis, respectively. The gas exchange of higher plants is particularly sensitive to the effects of the water deficit, as well
MELO, A. S. et al.

as the expected decrease of photosynthesis because of water reduction (LISAR et al., 2012). This photosynthesis reduction during water deficit occurs due to the decrease of $\mathrm{CO}_{2}$ availability inside the leaf tissue, which occurs because of the decline of stomatal conductance in response to reduced soil water availability (PEREIRA FILHO et al., 2015). This fact has been confirmed by other authors who evaluated water deficit effects on Citrulus lanatus Thumb. Mansf (Melo et al., 2010), Solanum melongena L. (SILVA et al., 2015), Phaseolus vulgaris L. (ENDRES et al., 2010; NINOU et al., 2013), and Vigna unguiculata [L.] Walp. (SINGH; REDDY, 2011). In the 'Juazeiro' melon, there was a strong correlation among net photosynthesis, stomatal conductance, and internal carbon concentration (Table 1), in which the lowest irrigation rates (40\% ETo) significantly decreased stomatal conductance and, therefore, internal $\mathrm{CO}_{2}$ and net photosynthesis as well (Figure 3A, 3B, and 3D).
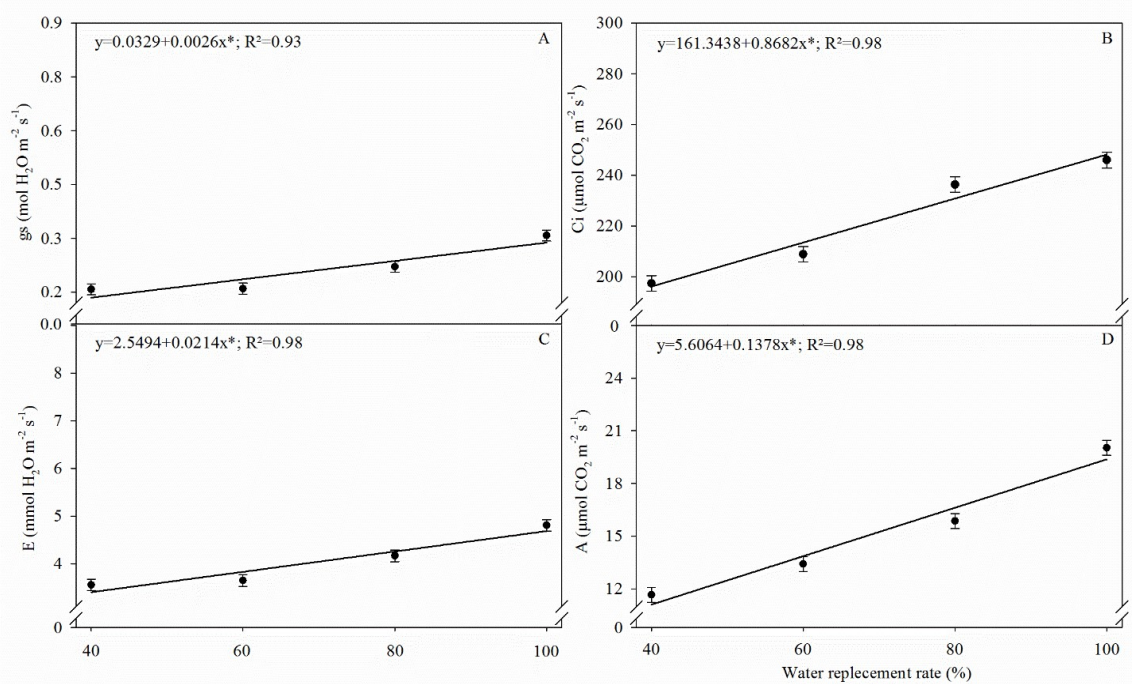

Figure 3. 'Juazeiro' melon stomatal conductance (gs A), internal carbon concentration (Ci-B), transpiration (E$\mathrm{C})$, and net photosynthesis (A-D) under different ETo replacement rates.

In addition to the limitations of the influx of $\mathrm{CO}_{2}$ caused by the stomatal closure, the decrease of photosynthesis activity may be related to damage caused to photosynthetic metabolism (ENDRES et al., 2010; LISAR et al., 2012). Thus, reductions in 'Juazeiro' melon quantum efficiency of photosystem II, under the lowest ETo replacement rates (Figure 4b), may be involved in the drop of the photosynthetic rate as seen by the strong positive correlation observed among the variables (Table 1). Lisar et al. (2012) reported that several cofactors cause damage to photosynthetic metabolism and, thus, the decrease of plant photosynthesis under water stress, among them qualitative and quantitative changes in the photosynthetic pigments pool. Such changes may be identified by the assessment of chlorophyll $a$ fluorescence (SUASSUNA et al., 2011; SILVA et al., 2015).

There was a reduction in melon plants transpiration (E) under the lowest irrigation rates (Figure 3c) as a result of decreased stomatal conductance under limited water conditions, as can be observed by the positive correlation between stomatal conductance and transpiration $(r=0.87$ **). Furthermore, usually, transpiration follows the same trend of net photosynthesis as $\mathrm{CO}_{2}$ assimilation is connected to plant water loss to the environment. This hypothesis is confirmed by the 
correlation observed between these variables $(\mathrm{r}=$ $0.71 * *)$.

The increment in melon plants transpiration, with the increase of water replacement rates, may be related to the better leaf cooling, which is required for the photosynthetic process, as well the high evaporative demand by the atmosphere in semi-arid regions. Thus, it can be inferred that the low transpiration observed at 40\% ETo (Figure 3c) may have contributed to the thermal stress on leaves and decreased the photosynthesis even more (Figure 3d). The increase in leaf temperature as a function of water deficit has also been verified in plants such as Solanum melongena L. (SILVA et al., 2015) and Phaseolus vulgaris L. (ENDRES et al., 2010), consequently being related to the photosynthetic rate decreases.

Unlike the above-mentioned gas exchange parameters (gs, Ci, E, and A), instantaneous water use efficiency (iWUE) was described by a quadratic polynomial model with the estimated maximum value $\left(4.33 \mu \mathrm{mol} \mathrm{CO}_{2} \mathrm{~mol}^{-1} \mathrm{H}_{2} \mathrm{O}\right)$ achieved with the estimated rate of $80.5 \%$ ETo (Figure $4 \mathrm{a}$ ). In contrast, 40\% ETo application reduced 'Juazeiro' melon instantaneous water use efficiency by $34.1 \%$. Low values of instantaneous water use efficiency, observed under $40 \%$ and $60 \%$ ETo, may be associated with decreases in stomatal conductance
(Figure 3a), with direct consequences on photosynthesis, which may be confirmed by the positive linear correlation between net photosynthesis and instantaneous water use efficiency $\left(r=0.63^{* *}\right)$. On the other hand, the decrease of instantaneous water use efficiency, with the increase in more than $80.5 \%$ ETo replacement, may be linked to high rates of $\mathrm{E}$ observed under higher water replacement (Figure 2c). This is explained by the fact that iWUE represents the amount of carbon fixed by the plant per unit of water lost through transpiration.

Quantum efficiency of photosystem II (Fv/Fm) can be used as a stress indicator in plants (SILVA et al., 2011; FERRAZ et al., 2014; SILVA et al., 2015), because it may be evaluated without damage to the plant (SUASSUNA et al., 2011). 'Juazeiro' melon quantum efficiency of photosystem II was reduced with $40 \%$ ETo application, with the minimum estimated at 0.79 (Figure 4b). Also, the estimated maximum quantum efficiency of photosystem II (0.83) was observed with $89.6 \%$ of the reference evapotranspiration rate application. However, the Fv/Fm indices are above 0.75, considered as a critical value of the photosystem, indicating that stress did not damage the photosynthetic apparatus of the plant (BAKER; ROSENQVIST, 2004).

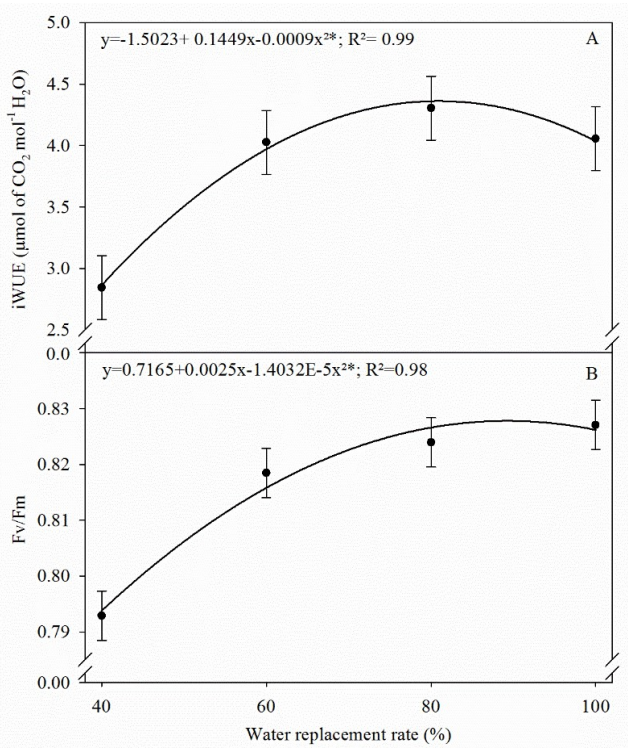

Figure 4. 'Juazeiro' melon instantaneous water use efficiency (iWUE) (A) and quantum efficiency of photosystem II, Fv/Fm (B) under different replacement rates ETo.

The decrease of photochemical efficiency under water stress results in the lessening of reducing power (NADPH) and energy (ATP) for photosynthesis biochemical phase and, therefore, carbon fixation restriction (SILVA et al., 2011; SILVA et al., 2015). Therefore, the increase in quantum efficiency of photosystem II, observed with the rise of water replacement (Figure 4b), may be considered an indication of better use and conversion of light energy by plants (FERRAZ et al., 2014). With the hypothesis above, a positive correlation was found $\left(\mathrm{r}=0.91^{* *}\right)$ between 
'Juazeiro' melon quantum efficiency of photosystem II and net photosynthesis (Table 1).

Declines in 'Juazeiro' melon quantum efficiency of photosystem II under water stress (40\% ETo) may be linked to the highest amount of photochemical energy introduced into leaves in relation to the capacity of using it by photosynthesis (SILVA et al., 2011). Such behavior must be triggered by a disturbance in photochemical efficiency, as observed by Suassuna et al. (2011) in 'Imperial' melon under water stress. In addition, the decrease of capacity to use photochemical energy may be associated with the decrease of leaf pigments. This behavior was shown in plants grown at the lower ETo replacement rates, which had yellow leaves when compared to plants under 100\% ETo replacement.

In relation to fruit production, water stress significantly reduced Piel de sapo melon productivity (1135 g per plant) related to the $40 \%$ ETo replacement rate (Figure 5). Decline in fruit production is a response of plants under soil water stress and it is related to reduction of the photosynthetic metabolism as a response of leaf area and photosynthetic metabolism, which was shown in the present study. Decrease in fruit production has been observed by Dogan et al. (2008) in 'Ananas F1' melon, Suassuna et al. (2011) in 'Imperial' melon, Cavalcanti et al. (2015) in 'Mandacaru' melon, and Rad, Ghasemi and Koohpayegani (2017) in 32 accessions of melon plants. However, despite the reductions observed in fruit production due to the decrease in water availability, fruit yield at $80 \%$ ETo was higher than the values obtained by Suassuna et al. (2011) in 'Imperial' melon and Cavalcanti et al. (2015) in 'Mandacaru' melon.

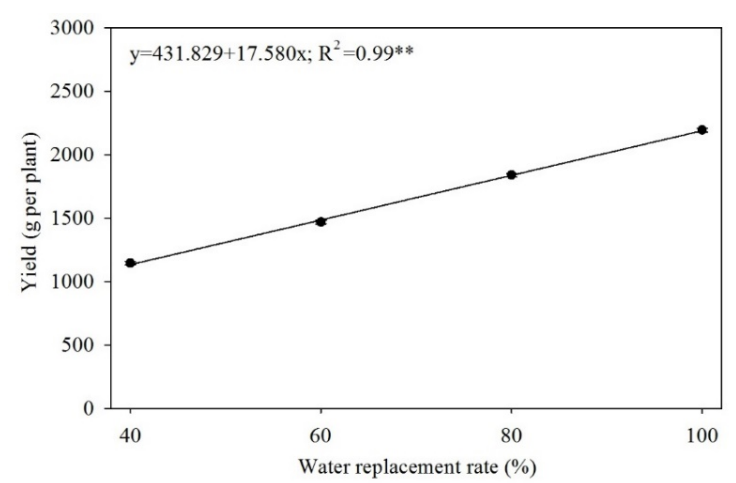

Figure 5. 'Juazeiro' melon fruit production under different ETo replacement rates.

Water replacement rates from $40 \%$ to $100 \%$ ETo promoted an increase of $92.95 \%$ in 'Juazeiro' melon fruit production, which reached maximum value of $2190 \mathrm{~g}$ per plant (Figure 5). This fruit production value indicates an average increase of $10.55 \mathrm{~g}$ per unit added in irrigation. These results must be associated with the maintenance of physiological activities, which have are directly related to plant growth and fruit productivity. A positive and significant correlation was observed between 'Juazeiro' melon leaf area and fruit production, which may be indicative of improvement in the production of photo-assimilates that are necessary to increase fruit production. This hypothesis may be reinforced by the positive correlation $\left(r=0.98^{* *}\right)$ between fruit production and net photosynthesis of Piel de sapo melon plants (Table 1).

\section{CONCLUSIONS}

Application of water replacement rates of $100 \%$ ETo leads to the highest growth, net photosynthesis, and fruit production in 'Juazeiro' melon.

Water replacement of $80 \%$ ETo can be used for growing 'Juazeiro' melon under semi-arid climate conditions, with small fruit yield losses.

Water replacement with rates less than $80 \%$ ETo causes drastic reductions in 'Juazeiro' melon growth, gas exchange, quantum efficiency of photosystem II, and fruit production, which impairs its yield in semi-arid climate environments.

RESUMO: O meloeiro (Cucumis melo L.) é uma cultura de grande importância social e econômica mundial, principalmente em regiões de clima semiárido como o Nordeste brasileiro, onde déficit hídrico é condição comum e considerado o principal fator de redução da produtividade das plantas. Tal fenômeno força a 
Physiology and yield...

MELO, A. S. et al.

utilização da irrigação como forma de disponibilizar a quantidade de água necessária à produção. Assim, objetivou-se com este trabalho avaliar as variações fisiológicas e produtivas de meloeiro pele-de-sapo submetidos a diferentes taxas de reposição hídrica. O híbrido 'Juazeiro' de melão pele-de-sapo foi cultivado sob quatro taxas de reposição da evapotranspiração de referência (40, 60, 80 e 100\% da ETo), distribuídas em blocos ao acaso com 5 repetições. As plantas foram cultivadas em campo, em área experimental situada no Nordeste brasileiro, em condições clima semiárido quente e seco, e durante o ciclo de cultivo as plantas de meloeiro híbrido 'Juazeiro' foram avaliadas quanto a área foliar, o acúmulo de biomassa, as trocas gasosas, eficiência fotoquímica do fotossitesma PSII e produção de frutos por planta. A aplicação de taxas de reposição hídrica a $100 \%$ da ETo proporciona o maior crescimento, fotossíntese liquida e produção do meloeiro 'Juazeiro'. A reposição hídrica a $80 \%$ da ETo pode ser usada para o cultivo do meloeiro 'Juazeiro' em condições de clima semiárido, admitindo-se pequenas perdas no rendimento. A reposição hídrica com lâminas inferiores a $80 \%$ da ETo promove reduções drásticas no crescimento, trocas gasosas, eficiência quântica do fotossistema II e produção, que inviabilizam a produção do meloeiro em ambientes de clima semiáridos.

PALAVRAS-CHAVE: Rendimento de frutos. Trocas gasosas. Eficiência fotoquímica.

\section{REFERENCES}

\section{ALLEN, R. G.; PEREIRA, L. S.; RAES, D.; SMITH, M. Crop evapotranspiration: guidelines for} computing crop water requirements. Roma: FAO, 1998. 300p.

BAKER, N. R.; ROSENQVIST, E. Applications of chlorophyll fluorescence can improve crop production strategies: an examination of future possibilities. Journal of Experimental Botany, Oxford, v.55, n.403, p.1607-1621, Jul. 2004. https://doi.org/10.1093/jxb/erh196

CAVALCANTI, F. J. A. Recomendações de adubação para o estado de Pernambuco. 2.apro. Recife: IPA, 2008. 212p.

CAVALCANTI, N. M. S.; DUTRA, A. F.; MELO, A. S.; SILVA, F. G.; DUTRA, W. F.; NUNES JÚNIOR, E. S. Aspectos agronômicos do meloeiro 'Mandacaru' cultivado em ambiente protegido sob irrigação. Irriga, Botucatu, v. 20, n. 2, p. 261-272, Apr./Jun., 2015. http://dx.doi.org/10.15809/irriga.2015v20n2p261

DOGAN, E.; KIRNAK, H.; BEREKATOGLU, K.; BILGEL, L.; SURUCU, A. Water stress imposed on muskmelon (Cucumis Melo L.) with subsurface and surface drip irrigation systems under semi-arid climatic conditions. Irrigation Science, New York, v. 26, n. 2, p. 131-138, Jan. 2008. https://doi.org/10.1007/s00271007-0079-7

EMBRAPA - Empresa Brasileira de Pesquisa Agropecuária. Sistema brasileiro de classificação de solos. 3.ed. Brasília: EMBRAPA 2013. 353p.

ENDRES, L. SOUZA, J. L.; TEODORO, I.; MARROQUIM, P. M. G.; SANTOS, C. M.; BRITO, J. E. D. Gas Exchange alteration caused by water deficit during the bean reproductive stage. Revista Brasileira de

Engenharia Agrícola e Ambiental, Campina Grande, v. 14, n. 1, p. 11-16, Jan. 2010. http://dx.doi.org/10.1590/S1415-43662010000100002

FAO. FAOSTAT. Available at: http://faostat3.fao.org. Access on: Feb 152017.

FERRAZ, R. L. S.; BELTRÃO, N. E. M.; MELO, A. S.; MAGALHÃES, I. D.; FERNANDES, P. D.; ROCHA, M. S. Trocas gasosas e eficiência fotoquímica de cultivares de algodoeiro herbáceo sob aplicação de silício foliar. Semina: Ciências Agrárias, Londrina, v. 35, n. 2, p. 735-748, Mar./Apr., 2014. http://dx.doi.org/10.5433/1679-0359.2014v35n2p735

IBGE. Produção agrícola municipal. Lavoura temporária melão. Produção e área plantada de melão, Brasil. 2014. Available at: http://www.sidra.ibge.gov.br/pesquisa/pam. Access on: Feb 152017. 
LISAR, S. Y. S.; MOTAFAKKERAZAD, R.; HOSSAIN, M. M.; RAHMAN, I. M. M. Water stress in plants: causes, effects and responses. In: I.M.M. Rahman, Hasegawa H (eds), Water Stress. Intech, Rijeka, Croácia, pp 1-14, 2012.

MANTOVANI, E. C.; BERNADO, S.; PALORETTI, L. F. Irrigação: princípios e métodos. 6 ed. Viçosa: Imprensa Universitária, 2006.

MEDEIROS, D. C.; MEDEIROS, J. F.; BARBOSA, M. A. G.; QUEIROGA, R. C. F.; OLIVEIRA, F. A.; FREITAS, W. E. S. Crescimento do melão Pele de Sapo, em níveis de salinidade e estágio de desenvolvimento da planta. Revista Brasileira de Engenharia Agrícola e Ambiental, Campina Grande, v.16, n.6, p.647-654, Jun. 2012. http://dx.doi.org/10.1590/S1415-43662012000600009

MELO, A. S.; SUASSUNA, J. F.; FERNANDES, P. D.; BRITO, M. E. B.; SUASSUNA, A. F.; AGUIAR NETTO, A. O. Crescimento vegetativo, resistência estomática, eficiência fotossintética e rendimento do fruto da melancieira em diferentes níveis de água. Acta Scientiarum Agronomy, Maringá, v.32, n. 1, p.73-79, Jan./Mar., 2010. http://dx.doi.org/10.4025/actasciagron.v32i1.213610.4025/actasciagron.v32i1.2136

NASCIMENTO, I. B.; FARIAS, C. H. A.; SILVA, M. C. C.; MEDEIROS, J. F.; SOBRINHO, J. E.; NEGREIROS, M. Z. Estimativa da área foliar do meloeiro. Horticultura Brasileira, Brasília, v. 20, n. 4, p. 555-558, Oct./Dec., 2002. http://dx.doi.org/10.1590/S0102-05362002000400009

NINOU, E.; TSIALTAS, J. T.; DORDAS, C. A.; PAPAKOSTA, D. K. Effect of irrigation on the relationships between leaf gas exchange related traits and yield in dwarf dry bean grown under Mediterranean conditions. Agricultural Water Management, Amsterdam, v. 116, n. 1, p. 235-241, Jan. 2013.

https://doi.org/10.1016/j.agwat.2012.08.002

PEREIRA FILHO, J. J.; BEZERRA, F. M. L.; CHAGAS, K. L.; SILVA, T. C.; PEREIRA, C. C. M. S. Trocas gasosas e fitomassa seca da cultura do meloeiro irrigado por gotejamento nas condições semiáridas do Nordeste. Irriga, Botucatu, v. 9, n. 1, p. 171-182, Jan./Mar. 2015. http://dx.doi.org/10.7127/RBAI.V9N300286

PINHEIRO NETO, G. P.; VIANA, T. D. A.; AZEVEDO, B. D.; FREITAS, J. D.; SOUZA, V. D. Produção e qualidade dos frutos de meloeiro submetido a redução hídrica na fase final do ciclo. Irriga, v. 12, n. 01, p. 5462, Jan./Mar. 2007. http://dx.doi.org/10.15809/irriga.2007v12n1p54-62

RAD, M. R. N.; GHASEMI, M. M.; KOOHPAYEGANI, J. A. Evaluation of melon (Cucumis melo L) genotypes aiming effective selection of parents for breeding directed at high yield under drought stress condition. Journal of Horticultural Research, Alexandria, v. 25, n. 1, p. 125-134, Jan. 2017.

https://doi.org/10.1515/johr-2017-0013

SILVA, P. E. M.; SANTIAGO, E. F.; SILVA, E. M.; SÚAREZ, Y. R.; DALOSO, D. M. Fluorescência da clorofila $a$ e variação da simetria como ferramentas de investigação de plantas sob estresse. Idesia, Arica, v. 29, n. 1 p. 45-52, Jan./Mar. 2011. https://doi.org/10.4067/S0718-34292011000300007

SILVA, F. G.; DUTRA, W. F.; DUTRA, A. F.; OLIVEIRA, I. M.; FILGUEIRAS, L. M. B.; MELO, A. S. Trocas gasosas e fluorescência da clorofila em plantas de berinjela sob lâminas de irrigação. Revista Brasileira de Engenharia Agrícola e Ambiental, Campina Grande, v. 19, n. 10, p. 946-952, Oct.. 2015. http://dx.doi.org/10.1590/1807-1929/agriambi.v19n10p946-952

SINGH, S. K.; REDDY, K. R. Regulation of photosynthesis, fluorescence, stomatal conductance and water-use efficiency of cowpea (Vigna unguiculata [L.] Walp.) under drought. Journal of Photochemistry and Photobiology B: Biology, Lausanne, v.105, n. 1, p.40-50, Jan. 2011.

http://dx.doi.org/10.1016/j.jphotobiol.2011.07.001 
Physiology and yield...

MELO, A. S. et al.

SUASSUNA, J. F.; MELO, A. S.; COSTA, F. S.; FERNANDES, P. D.; FERREIRA, R. S.; SOUSA, M. S. S. Eficiência fotoquímica e produtividade de frutos de meloeiro cultivado sob diferentes lâminas de irrigação.

Semina: Ciências agrárias, Londrina, v.32, n. 4, p.1251-1262, Oct./Dec., 2011.

http://dx.doi.org/10.5433/1679-0359.2011v32n4p1251

TERCEIRO NETO, C. P. C.; GHEYI, H. R.; MEDEIROS, J. F.; DIAS, N; S.; SILVA, M. V. T.; LIMA, K. S. Crescimento do meloeiro 'Pele de sapo' irrigado com água salobra com diferentes estratégias de manejo.

Revista Caatinga, Mossoró, v. 27, n. 2, p.87-100, Apr./Jun., 2014. 